A preliminary report from D. H. Carver and D. S. Y. Seto $^{1}$ indicates that the causative agent of serum hepatitis may have been isolated by cell culture techniques. This is not the first time that reports of the isolation of hepatitis virus have been made, but this one does look encouraging. Studies by $\mathbf{R}$. Ward and his colleagues ${ }^{2}$ have shown that specially modified immune globulin added to the blood before transfusion reduced the incidence and severity of post-transfusion hepatitis. S. Krugman and his colleagues ${ }^{3}$ have now shown that an antibody response to the Australia antigen can be detected in patients with serum henatitis if a sufficiently sensitive serological test is used. If this is confirmed, the development of specific prophylactic measures becomes a possibility. Now a report from Krugman and colleagues ${ }^{4}$ suggests that they have achieved active immunization.

\footnotetext{
1 Carver, D. H., and Seto, D. S. Y., "Production of haemadsorptionnerative areas by sera containing Australia antigen," Conference on Vira! Hepatitis at the Centre Internationale de l'Enfance, Paris, 14-18 June 1971. To be published in American Fournal of Diseases of Children.

2 Ward, R., Katz, R., and Rodriquez, J., "Post-transfusion hepatitis; cffict of modificd samma globulin added to blood transfusion," Conference on Viral Hepatitis, Paris, 1971.

3 Krurm?n, S., Gil-s, J. P., and Hammond, J., "Viral Hepatitis, type B(Mc-2 strain): studi-, on active immunization," Conference on B(MC-2 strain): studi-c on
Viral Hepatitis, Paris, 1971 .

4 Krueman, S., Giles, J. P., and Hammond, Fournal of the American Medical Association, 1971, 217, 41.
}

\section{Violence in Hospitals}

The tragic events at Farleigh Hospital ${ }^{12}$ occasioned the latest in a long list of alarming reports about the ill treatment of patients in our mental hospitals, particularly those caring predominantly for the mentally subnormal. In all institutions the misconduct of a very few can redound to the discredit of all. The innocent can understandably feel aggrieved at this injustice to the point where the desire to protect their own reputation may lead them to resign from the institution they have loyally served. If they decide to stay, they are justified in demanding to know from their superiors and their employers what went wrong and how such tragedies can be avoided in the future.

It was this situation which provoked the nurses at Farleigh to address a petition to the Secretary of State. ${ }^{3}$ In the petition simple questions are asked which in the main are concerned with the problem of violence-violence of a patient towards himself, violence towards his fellow patients, and, not least in importance, violence of a patient towards the staff. It seems likely that one of the recommendations in the report on the disaster was inspired by these vital questions. It reads: "A code of conduct for nurses in the handling of violent and difficult patients should be considered by representatives of the psychiatric and nursing professions."

Now the National Association for Mental Health has issued a pamphlet ${ }^{4}$ which may be seen as a response to that recommendation, though it is not explicitly stated to be so. Unfortunately it is not an altogether satisfactory document. Perhaps too much was attempted in too little space. In only four pages of large print there are 13 items in its "guidelines." A brief prefatorial statement remarks, for example, that "incidents of violence are not a common occurrence." On what evidence is this somewhat facile statement made?
Have any attempts been made to quantify episodes of violence in our hospitals comparable with work recently done in Sweden? ${ }^{5}$ There, incidentally, in a cross-sectional study of its mental hospital ponulation on 6 April 1965 it was shown that about $8 \%$ of the patients were classified as dangerous. Again, the pamphlet refers to "The use of physical methods of control, such as restraint or segregation." Does restraint mean the descent of a squad of muscular male nurses, or the use of old-fashioned instruments such a straitwaistcoats, muffs, leg-locks, and the like? What is segregation? Does it mean simply ostracism, or restriction to a locked single room, or even confinement in a padded cell? These are not pernickety details: they are of central importance to the whole issue.

Perhaps the most disconcerting statement is that which discusses the admission of a patient "who may require a high level of security because of his violent or unpredictable behaviour." If the hospital concerned is one of the special hospitals, there is no alternative to admission if a court so directs. But in a conventional hospital it is preposterous that this situation should ever arise. That it does is of course undeniable, and it reflects sadly on the present inadequacy of accommmodation for the care of known dangerous patients, or, for that matter, patients who as an expression of their mental disorder become dangerous. Repeated protests have been made in these columns about this grievous situation, ${ }^{6-8}$ and the same protest can only be made again.

Despite its defects this pamphlet does serve to highlight the fact that our mental nurses must accept as an occupational hazard the risk of being at the receiving end of violent attacks. It is hoped that more detailed and authoritative advice will be forthcoming in response to the appeal from the Farleigh nurses, which must reflect the anxiety of all nurses who do their best in an honourable and exacting service.

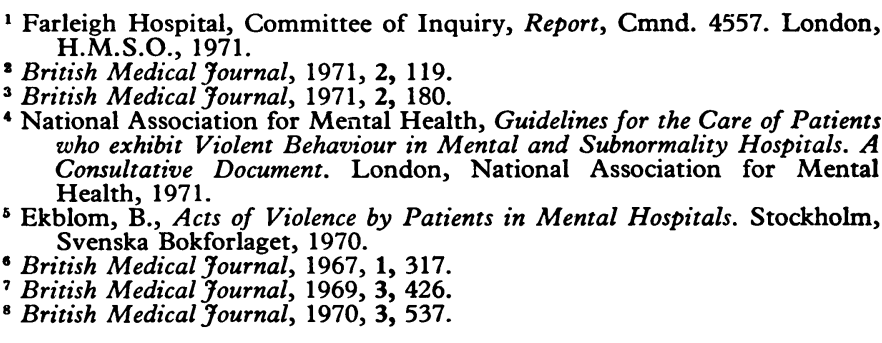

\section{Napkin Psoriasis}

Probably few infants pass through their first two years without at least some brief attacks of erythema in the napkin area. So many social and psychological factors influence a mother's decision to consult her doctor and the latter's decision to refer the child to a dermatologist that hospital statistics of incidence are difficult to evaluate. Conclusions drawn by comparing such statistics from different countries are meaningless. The lack of uniformity in the nomenclature of the various patterns of napkin eruptions makes it equally difficult to establish whether any particular type is increasing in frequency.

Napkin psoriasis is no new disease. Many authors have preferred to call it psoriasiform seborrhoeic dermatitis. ${ }^{1}$ It affects infants between 1 week and 9 months old (usually 4 to 12 weeks), develops rapidly, and often reaches its 